\title{
Planning and Arun's \\ (not so Straight and Narrow) Roads
}

J van Wyk

\section{P.R.R}

Author

Jeannie van Wyk

Affiliation

University of South Africa

South Africa

Email vwykama@unisa.ac.za

Date published 26 April 2016

Editor Prof AA du Plessis

How to cite this article

Van Wyk J "Planning and Arun's

(not so Straight and Narrow)

Roads" PER / PELJ 2016(19) -

DOI

http://dx.doi.org/10.17159/1727-

3781/2016/v19i0a1162

\section{Copyright}

This work is licensed under a Creative Commons Attribution 4.0 International License.

DOI

http://dx.doi.org/10.17159/17273781/2016/v19i0a1162

\section{Abstract}

Arun Property Development (Pty) Ltd wished to subdivide portions of the farm Langeberg 311, Durbanville. The 1988 structure plan for the area had indicated that certain roads would traverse the property. These and other roads all formed part of a new subdivision known as Sonstraal Heights. As is customary, the ownership of the roads in the subdivision vested in the municipality in terms of section 28 of the Land Use Planning Ordinance 15 of 1985 (C) (LUPO) on the date of approval of the subdivision. Central to this provision is that no compensation is payable to the developer if the provision of the public roads is based on the normal need therefor arising from the subdivision. Since the developer was of the opinion that the roads it had provided exceeded the normal need, the issue that had to be resolved was whether compensation must be paid for roads beyond what would normally be required for a subdivision. The main issue that the courts, from the Western Cape High Court to the Constitutional Court in Arun Property Development (Pty) Ltd $v$ City of Cape Town 20152 SA 584 (CC), had to deal with was whether the vesting of roads beyond the normal need therefor arising from the subdivision amounted to an expropriation of land for which compensation is payable in terms of section 25(2) of the Constitution. This case note looks at the different stages of the case, and in the process highlights the historical and legislative background and the subdivision process. It shows that the vesting of the ownership of roads in the municipality is similar to the payment of a development contribution, both of which can be categorised as deprivations of property in terms of the constitutional property clause. On 1 July 2015 LUPO was effectively superseded by the new Spatial Planning and Land Use Management Act 16 of 2013 (SPLUMA) and the Western Cape Land Use Planning Act 3 of 2014 (LUPA). Since SPLUMA does not and LUPA does contain a reference to the "normal needs" provision, the implications of Arun for the new legislative dispensation are addressed.

\section{Keywords}

Subdivision of land; public roads; deprivation; expropriation. 
Arun Property Development (Pty) Ltd and the City of Cape Town were at odds about the status of public roads in a new subdivision, or neighbourhood, known as Sonstraal Heights. Essentially, the issue was whether compensation should be paid for public roads or parts of public roads that were outside the normal need therefor arising from the subdivision, where ownership of these roads had been transferred to the municipality as part of the process of the subdivision of land regulated in terms of the Western Cape Land Use Planning Ordinance 15 of 1985 (hereafter LUPO). The developer was of the opinion that since the roads that it had provided exceeded those required to service the normal need, compensation must be paid for the roads provided in excess of what would normally be required for a subdivision. The dispute with the City arising from this demand played out in a number of court applications, the final one being in the Constitutional Court. ${ }^{1}$

The intention of the developer was that the development take place on portions 57 and 61 of the farm Langeberg 311, Durbanville, consolidated to form Erf 10357. The land was 52,09ha in extent and was subdivided into 2 portions, Portion A being 31,80ha in extent and Portion B 20,29ha. As part of the process of the subdivision of land, ${ }^{2}$ township establishment ${ }^{3}$ or land development ${ }^{4}$ a number of roads, approximately 31 ha in extent, were envisaged to traverse the property.

* Jeannie van Wyk. BBibl (Pret), LLB (Unisa), LLM (Wits), LLD (Unisa). Professor of Law, University of South Africa. Email: vwykama@unisa.ac.za. This case note is based on a paper read at the joint University of Johannesburg/South African Research Chair in Property Law day seminar on Arun Property Development (Pty) Ltd $v$ City of Cape Town 20152 SA 584 (CC), held at the Constitutional Court on 15 July 2015 . I wish to express my sincere gratitude to the anonymous peer reviewers for their valuable comments.

1 Arun Property Development (Pty) Ltd v City of Cape Town 20152 SA 584 (CC) (hereafter Arun CC). Also see Arun Property Development (Edms) Bpk $v$ Stad Kaapstad 2005 ZAWCHC 86 (15 November 2005) (hereafter Arun 2005 ZAWCHC); Arun Property Development (Pty) Ltd v City of Cape Town 2012 ZAWCHC 399 (31 October 2012) (hereafter Arun 2012 ZAWCHC); City of Cape Town v Arun Property Developments (Pty) Ltd 2014 ZASCA 56 (16 April 2014) (hereafter City of Cape Town $v$ Arun SCA).

2 The terminology used in the Land Use Planning Ordinance 15 of 1985 (Cape) (LUPO) and Northern Cape Planning and Development Act 7 of 1998. While the more general term is "township establishment", the term "subdivision of land" is preferred here because it is the term applied in LUPO.

3 Terminology used in other spatial planning legislation such as the Town Planning and Townships Ordinance 15 of 1986 (Transvaal) etc.

4 Terminology used in the Spatial Planning and Land Use Management Act 16 of 2013 (SPLUMA). In July 2015 SPLUMA came into operation throughout South Africa. 
The subdivision took place in three phases, ${ }^{5}$ commencing in 1998 and completed in 2002. As is customary in the subdivision process, the ownership of the roads in the subdivision vested in the municipality in terms of section 28 of $\angle U P O^{6}$ on the dates of the approval of the subdivisions.

The roads that were in issue and for which compensation was originally claimed are:

1. Main Road 81 and the R300 extension (19,303 ha) (the municipality required that the road be $32 \mathrm{~m}$ wide instead of a normal $16 \mathrm{~m}$ ). This is a provincial road still to be constructed. It will traverse the open tract of land on the left side (the west) of the map below. The compensation issue must still be decided.

2. Other streets: $(12,3660$ ha - The Arun cases deal with these roads)

a. Brackenfell Boulevard (the M100) (the entire road was viewed as being in excess since nothing was required for normal needs);

b. Verdi Boulevard and Belami Avenue (the municipality required $20 \mathrm{~m}$ in width instead of $16 \mathrm{~m}$ );

c. De Villiers Drive extension, (from Verdi Boulevard to Brackenfell Boulevard; nothing was required for normal need); from R300 to Verdi Boulevard (the municipality required $32 \mathrm{~m}$ in width instead of $16 \mathrm{~m}$ ).

The map below shows the entire Sonstraal Heights development. All of the roads are clearly indicated, and it is evident that the roads in issue in Arun are, for the most part, external to the subdivision, not the "internal" roads that are an essential part of the subdivision.

While it does not repeal any provincial legislation it effectively supersedes provincial legislation that is inconsistent with it. See s 2(2) of SPLUMA. See further 5 below.

5 The first phase related to the area north of De Villiers Drive and west of Brackenfell Boulevard, the second phase related to the area south of De Villiers Drive and east of Verdi Boulevard, and the third phase related to the area south of De Villiers Drive and west of Verdi Boulevard.

6 LUPO has been repealed in the Western Cape by the Western Cape Land Use Planning Act 3 of 2014 (LUPA), that (except for ss 22(4), 25, 26, 27, 28(c) and 66(4)(c)) came into operation in the City of Cape Town on 1 July 2015. (Other municipalities will follow.) In the Northern Cape LUPO was repealed by the Northern Cape Planning and Development Act 7 of 1998. 
Graphic 1: Map of Sonstraal Heights

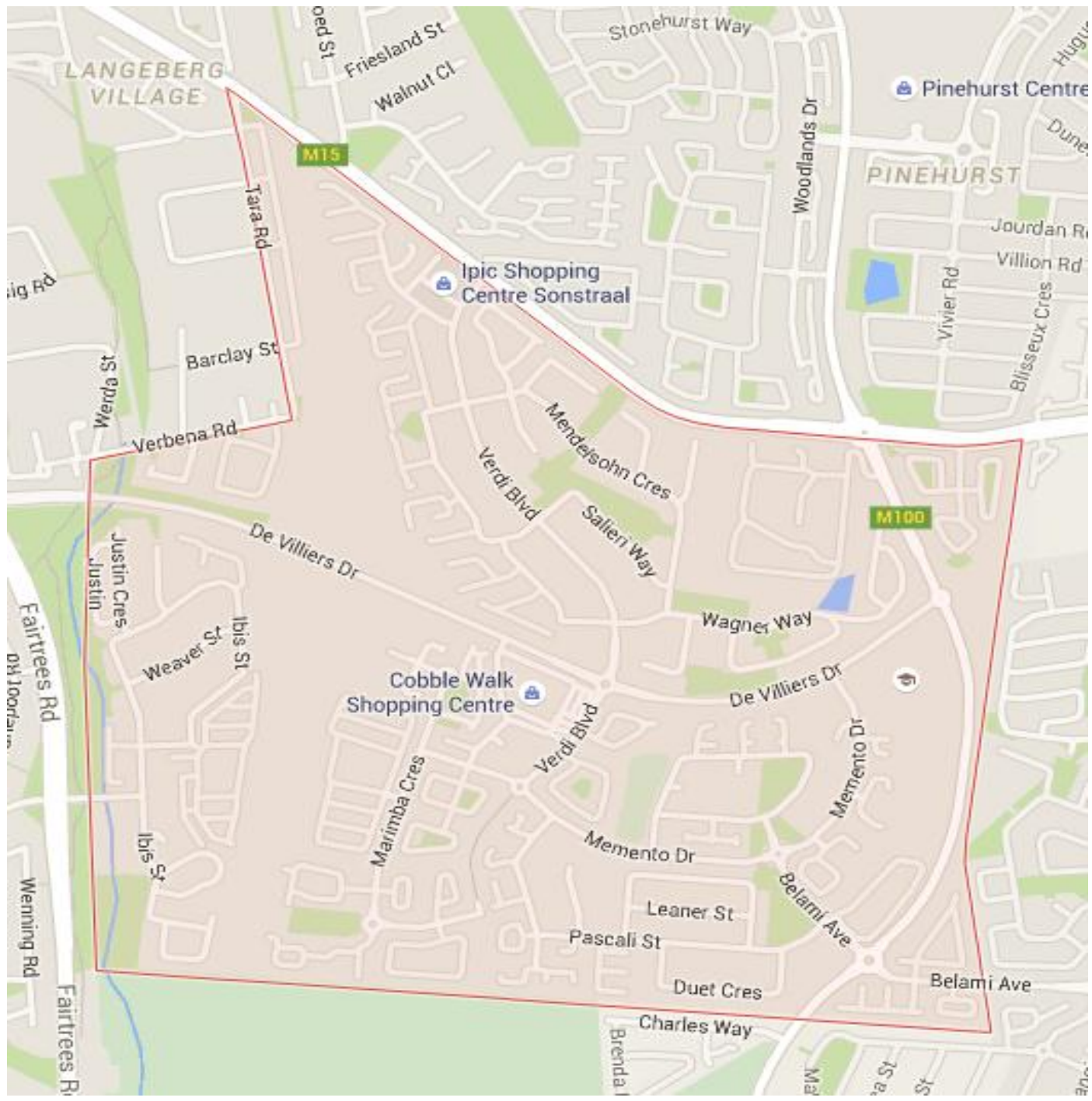

It is understandable that Arun was concerned about the fact that of the $52 \mathrm{ha}$ of its land, it was going to forfeit 31 ha for roads and public places. It first approached the Cape High Court $^{7}$ claiming compensation in the amount of R 55237561.00 for the alleged expropriation of the land. In the first exception argued before Erasmus $\mathrm{J}$ - that was dismissed - it was pointed out that the applicant was entitled to compensation to the extent that the provision of roads was not based on the normal need arising from the subdivision. ${ }^{8}$ The second and third exceptions, relating to the R300, being a trunk road proclaimed by the (then) Administrator, to which the provisions of LUPO did not apply, were upheld. ${ }^{9}$ Before Dlodlo $\mathrm{J}$ in the

Arun 2005 ZAWCHC.

Arun 2005 ZAWCHC para 33.

Arun 2005 ZAWCHC paras 35-41. 
Western Cape High Court ${ }^{10}$ Arun claimed that insofar as the right to ownership of public streets vested in the municipality in terms of section 28_of LUPO, such right of ownership is a "taking" as contemplated by section 26(1) of the Expropriation Act 63 of 1975. Relying on Heher J's minority judgment in the Helderberg case ${ }^{11}$ the court held that section 28 of LUPO is capable of meaning that the vesting of public places and streets beyond the normal need arising from a particular subdivision will give rise to a claim for compensation at the instance of the former owner of the land. ${ }^{12}$ The Supreme Court of Appeal disagreed with the reliance placed on Helderberg and upheld the municipality's appeal. ${ }^{13}$ Hence Arun's appeal to the Constitutional Court, which set aside the order of the Supreme Court of Appeal and re-instated the order of the Western Cape High Court in amended form, directing that the excess land - to be established or agreed upon by the parties - had vested in the City of Cape Town in terms of section 28 of LUPO. ${ }^{14}$ As a result Arun Property Development (Pty) Ltd was entitled to compensation in respect of that excess land, which had to be calculated in terms of the Expropriation Act.

Arising from this series of court cases are the following questions: 1 what is vesting? 2 why should roads vest? 3 which roads vested - all roads or only those that were for the normal need? 4 does the whole road vest or only the part for the normal need? 5 which roads were in excess of normal need? 6 if only a part of the road vested did the developer still own the other part? 7 is this expropriation? 8 is compensation payable?

At the very beginning of the Constitutional Court decision Moseneke DCJ puts the matter firmly in a constitutional context and indicates that:

This appeal raises a significant constitutional issue connected to the expropriation of land and compensation. It is whether a local authority that has acquired land, by operation of legislation, from a private owner in a planning approval process for a residential development, is obliged to pay compensation for the land so acquired. ${ }^{15}$

Emphasis must be placed on the phrase "a planning approval process for a residential development" because this points to the scenario that underpins the case. Arun is about specific planning law instruments and a

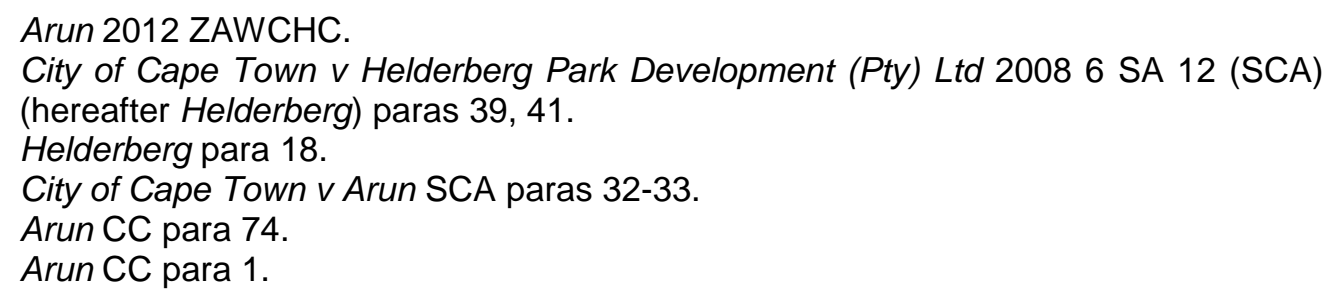


specific procedure - the subdivision of land. It is in that context that I look at the case and in the process highlight the historical and legislative background, the 1988 structure plan, and the subdivision process. As part of the subdivision process the distinction between the payment of development contributions and the vesting of roads in the municipality is highlighted. Invariably the interpretation of section 28 of LUPO is crucial. Finally, the implications of Arun for the new Spatial Planning and Land Use Management Act 16 of 2013 (hereafter SPLUMA) and the Western Cape Land Use Planning Act 3 of 2014 (hereafter LUPA), both of which in effect superseded LUPO on 1 July 2015, will be dealt with.

\section{$2 \quad$ Structure plan 1988}

Structure plans, in terms of $L U P O$, are old-order "important town planning and urban development tools". ${ }^{16}$ A structure plan has as its purpose:

... to lay down guidelines for the future spatial development of the area to which it relates (including urban renewal, urban design or the preparation of development plans) in such a way as will most effectively promote the order of the area as well as the general welfare of the community concerned. ${ }^{17}$

A structure plan must be drawn up by the municipality, ${ }^{18}$ and when submitted to the premier must be made available for inspection and the lodging of objections. ${ }^{19}$ After considering the objections, the premier approves or rejects the structure plan. ${ }^{20}$ It is meant to capture the local authority's vision for the use and development of the land within its jurisdiction. As such, it should provide a framework within which land use planning and development by the private sector takes place. ${ }^{21}$

The most important planning instrument that made provision for a hierarchy of roads over Erf 10357 is the 1988 structure plan. It burdened

16 Club Mykonos Langebaan Ltd $v$ Langebaan Country Estate Joint Venture 20093 SA 546 (C) (hereafter Club Mykonos) para 8. See further Van Wyk Planning Law 277.

17 LUPO s 5(1). The purpose of the structure plan was emphasised in Arun CC para 37 and Arun 2012 ZAWCHC para 27. See further Huisman $v$ Minister of Local Government, Housing and Works (House of Assembly) 19961 SA 836 (A) (hereafter Huisman) 839F; Esterhuyse v Jan Jooste Family Trust 19984 SA 241 (C) 247G-H, 253H; Ehlers v MEC: Dept of Environmental Affairs and Development Planning 2008 1 All SA 576 (C) (hereafter Ehlers) para 12; Club Mykonos para 8; Waenhuiskrans Arniston Ratepayers Association v Verreweide Eiendomsontwikkelings (Edms) Bpk 20113 SA 434 (WCC) para 157.

18 LUPO s 4(1)-(2). Also see Huisman 839F; Ehlers para 12.

19 LUPO s 4(5).

20 LUPO s 4(6).

21 Arun CC para 2. 
the property with a planned primary road system consisting of an order $1^{22}$ road, North/South, namely the Kuilsriver highway, ${ }^{23}$ and two order $2^{24}$ roads, namely the East/West De Villiers Drive extension ${ }^{25}$ and the North/South Brackenfell Boulevard in the East. The Sonstraal Heights subdivision is superimposed on the structure plan below with all three roads clearly indicated.

Graphic 2: 1988 Structure Plan indicating the (later and superimposed) location of Sonstraal Heights

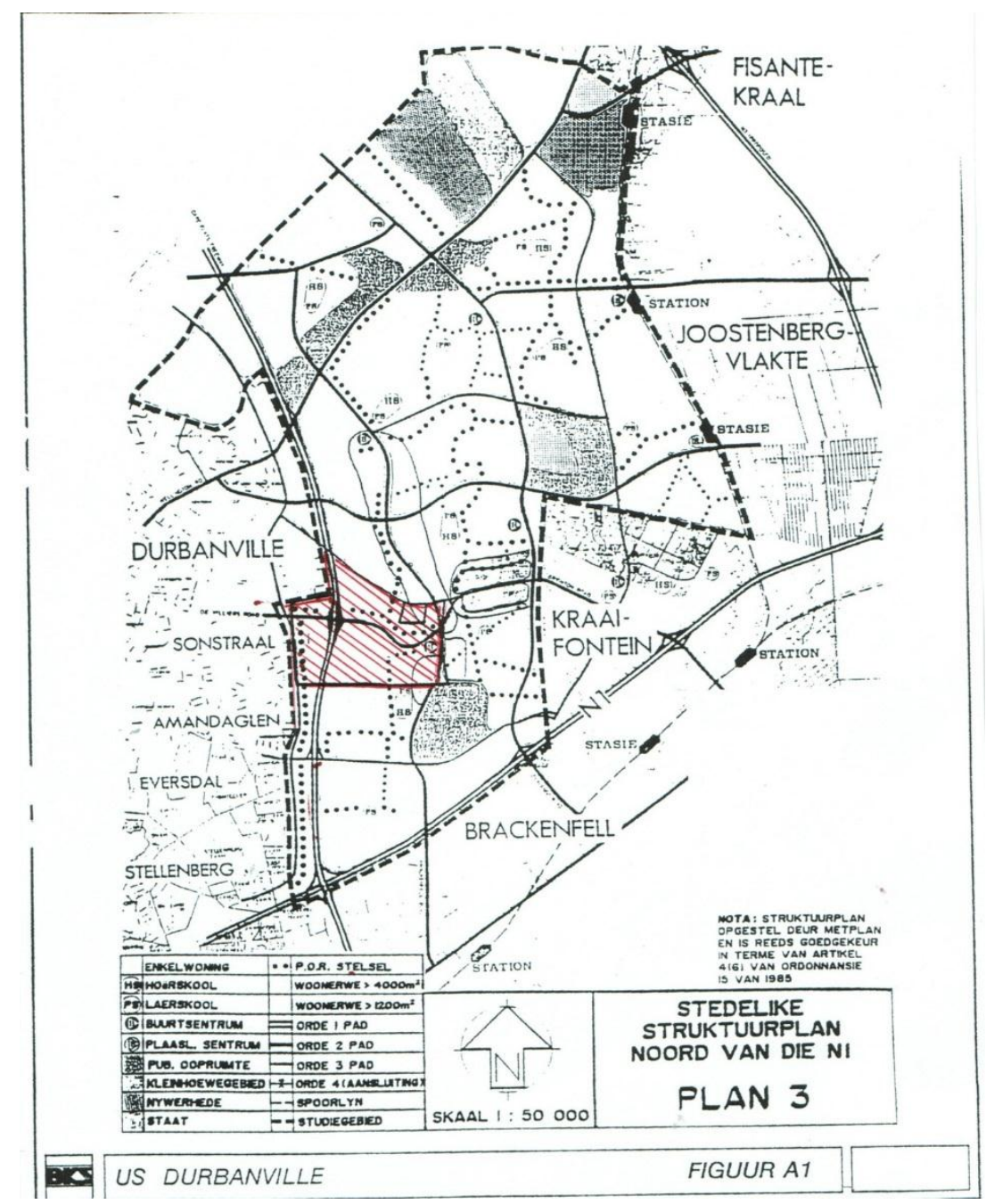

22 Trunk roads and main roads.

23 Previously known as Main Road 81 and currently known as Main Road 81 and the R300 extension. The fate of this is as yet undecided. This road has not yet been built.

24 Primary distributors.

25 Also known as Golf Course Road. 


\subsection{Effect of a structure plan}

In a constitutional context a structure plan is a section 25(1) deprivation, which, as was clear from the decision in Reflect-All, ${ }^{26}$ can have severe consequences for the owner of land affected by the road plan. For a private developer, the requirements set by a local authority in a structure plan are in many instances not easy to bypass or change. ${ }^{27}$ From the structure plan it is clear that Arun was severely impacted by the road plans. All the roads indicated on the structure plan had to be respected by Arun in its planning for the subdivision. This is alluded to on numerous occasions and in different language, such as that "Arun was obliged to provide for the planned primary road system over the property", ${ }^{28}$ and that the "requirements with regard to the road infrastructure ... had to be complied with." 29 What does this mean exactly - that Arun had to plan the subdivision around the planned roads, or that it had to actually provide for all the roads?

A number of issues arise with regard to this so-called obligation. The first of these is that if one thinks away the subdivision, the roads would still be indicated on the structure plan. When the time came for the municipality to build the roads, it would have to expropriate the land and pay compensation to the owner. ${ }^{30}$ Put differently, if new developments were not initiated by developers, the land necessary to enable the structure plan would in due course be expropriated with compensation to the land owners. ${ }^{31}$ The second (and related) issue is that a structure plan "shall not confer or take away any right in respect of land". ${ }^{32}$ In this regard land required for trunk roads, main roads and primary distributors such as those indicated on the structure plan could not merely be "taken away" in terms of the structure plan, but would have to be regulated in some way or other.

26 Reflect-All 1025 CC v MEC for Public Transport, Roads and Works, Gauteng Provincial Government 20096 SA 391 (CC) (hereafter Reflect-All).

27 Arun CC para 2.

28 Arun CC para 8.

29 City of Cape Town $v$ Arun SCA para 9.

30 See Arun CC para 35: "This becomes plain when one considers what the position is on land that is not subject to an application for subdivision that is needed by a local authority for a higher-order road in terms of a structure plan. When the local authority resolves that the time has come to build the road, the land must be expropriated and compensation must be paid to the owner".

31 Arun CC fn 3.

$32 \quad$ LUPO s 5(3). See also Arun CC para 37. 


\title{
2.2 Is the structure plan a policy?
}

One of the issues raised by the City was that the structure plan was a policy and that section 28 permitted the non-payment of compensation in accordance with a policy.

A policy and a plan are two different things: policy documents set out a framework, principles and guidelines, while tools and mechanisms such as legislation and other statutory instruments such as plans give effect to that overarching framework. The principles and guidelines contained in policy must be relayed to legislative and other measures that have to be implemented in order to change lives. ${ }^{33}$ Policies are multidimensional and incorporate all the relevant contexts, for example the geographical and ecological, political, economic, social and cultural, demographic, the global and strategic contexts. ${ }^{34}$ As against a policy, and in the words of the Cape High Court:

\begin{abstract}
...a structure plan is and remains a particular statutory instrument serving designated planning purposes and subject to detailed statutory requirements. It should capture the local authority's vision for the area concerned and serve as the municipal spatial development framework within which land use planning and development by the private sector is to take place... the guideline proposals included in the structure plan are used by the authorities in the evaluation of applications for rezoning, subdivisions and departures. ${ }^{35}$
\end{abstract}

There can be no argument with the findings of the High Court and the Constitutional Court not only in Arun but also in cases such as Club Mykonos Langebaan $v$ Langebaan Country Estate Joint Venture, ${ }^{36}$ that a structure plan cannot be equated with a policy.

Moreover, while a policy may contain principles regarding the provision of roads in a subdivision, it may not permit municipalities to acquire land free of the duty to compensate for planned public streets which exceed the normal needs of the subdivision. ${ }^{37}$ That must be regulated in terms of a plan, authorised by legislation. Consequently, the City's argument had no merit.

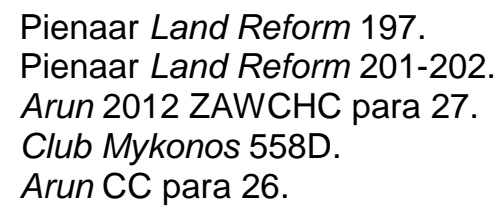




\section{Development applications}

In line with the structure plan, Arun proceeded with its application for subdivision - one of a number of different types of development applications. Development applications comprise a variety of applications that are submitted to a municipality for approval, such as amendments to town planning or land use schemes (rezonings), the removal of restrictive conditions, consent uses, consolidations, or subdivisions of land/township establishments.

\subsection{Subdivision / township establishment procedures}

A subdivision or "township development" means an area of land divided into erven, and may include public places and roads indicated as such on a general plan. ${ }^{38}$ The graphic below indicates the subdivision layout as envisaged by Arun Property Developers (Pty) Ltd.

Graphic 3: Subdivision Layout of Sonstraal Heights




Using the term "township development," the Supreme Court of Appeal describes the subdivision of land as:

\begin{abstract}
...an economic speculation that holds serious implications for both the developer and the public authority. The developer, for example, must balance the costs involved in the acquisition of the land, with legal, planning, marketing and infrastructural development expenses against a prediction of future market conditions, the potential of the land, competing developments and so on. The best interest of the local authority lies in the success of the development. It too has infrastructural costs recoverable in the medium to long term. A failed development represents a blot on its management and may involve it in the costs of salvaging the development. In these circumstances prudence requires that both parties exclude by their consensus as much uncertainty as they can at the outset. The development process is, of course, also designed to protect the persons who will be acquiring property in the development and will become its residents and users of its amenities. ${ }^{39}$
\end{abstract}

Complex and lengthy processes requiring agreements and inputs from the owner and/or developer and the municipality are required. In essence, township development comprises the surveying, planning, layout, development and supply of services on a defined portion of land to be laid out and divided into erven or sites zoned for specific purposes. ${ }^{40}$ Roads are an integral part of that process.

Although the provisions in terms of the different legislative instruments ${ }^{41}$ are similar, the procedure in terms of LUPO is that an owner of land applies for the subdivision of land. ${ }^{42}$ Applications must be advertised ${ }^{43}$ and where objections are received they must be submitted to the owner for comments. ${ }^{44}$ Comments from people who may have an interest in the application may be obtained. ${ }^{45}$ An important aspect of the process of the subdivision of land is the provision of services such as roads, water, electricity and sewerage. The required services are usually contained in an agreement between the township developer or the owner of land and the municipality. A distinction is made between internal engineering services that are the responsibility of the township developer and external engineering services, such as the provision of bulk water, sewerage or

39 Municipality of Stellenbosch v Shelf-Line 104 (Pty) Ltd 20121 SA 599 (SCA) (hereafter Shelf-Line) para 20.

40 See Van Wyk Planning Law 360-376.

41 See eg Townships Ordinance 9 of 1969 (Orange Free State); Town-planning and Townships Ordinance 15 of 1986 (Transvaal); Northern Cape Development and Planning Act 7 of 1998; KwaZulu-Natal Planning and Development Act 6 of 2008.

42 LUPO s 24(1).

$43 \quad L U P O$ s $24(2)(a)$.

$44 \quad$ LUPO s 24(2)(b).

$45 \quad$ LUPO s 24(2)(c). 
electricity, that are the responsibility of the municipality. ${ }^{46}$ It is necessary to take note of this in the context of roads as well. Once all the agreements are in place and the planning is completed the municipality grants or refuses the application. ${ }^{47}$ On approval section 28 comes into play, providing that the ownership of all roads vests in the municipality without compensation, if the roads are for the normal needs of the development. The approval of the application is often subject to conditions of approval imposed in terms of section 42(2) of LUPO.

\subsection{Conditions of approval}

It is necessary to deal with conditions of approval in terms of section 42 of LUPO, because this was raised by the court and was also a significant issue in the Helderberg case. ${ }^{48}$ This case and the question whether the minority decision could be followed was key to the decision of the Supreme Court of Appeal in Arun. Moreover, an important distinction can be made between section 42 and section 28 regarding the nature of the "obligation" or "transaction" involved.

Where there is intensified utilisation of the land and a consequent increase in loading on the infrastructure as a result of changes in land use or zoning and the municipality is of the opinion that public expenditure has been incurred in the past or will be incurred in the future and such expenditure arises from the subdivision, it may impose conditions of approval. ${ }^{49}$ Such conditions may include the cession of land or the payment of money that is directly related to the requirements resulting from the approval of the subdivision. ${ }^{50}$ In addition the municipality may require the payment of a

46 Van Wyk Planning Law 372-373.

47 See eg LUPO s 25. See Hayes $v$ Minister of Finance and Development Planning, Western Cape 20034 SA 598 (C); Helderberg para 32; Club Mykonos paras 31-33; Lagoon Bay Lifestyle Estate (Pty) Ltd $v$ The Minister of Local Government, Environmental Affairs and Development Planning of the Western Cape 20114 All SA 270 (WCC) paras 22-24; Shelf-Line.

48 City of Cape Town v Helderberg Park Development (Pty) Ltd 20086 SA 12 (SCA).

49 LUPO s 42 reads as follows: "(1) When the Administrator or a council grants authorisation ... he may do so subject to such conditions as he may think fit. (2) Such conditions may, having regard to- (a) the community needs and public expenditure which in his or its opinion may arise from the authorisation ... and the public expenditure incurred in the past which in his or its opinion facilitates the said authorisation ..., and (b) the various rates and levies paid in the past or to be paid in the future by the owner of the land concerned, include conditions in relation to the cession of land or the payment of money which is directly related to requirements resulting from the said authorisation, ... in respect of the provision of necessary services or amenities to the land concerned".

50 LUPO s 42(2). See also Helderberg para 55; Club Mykonos para 36; Shelf-Line paras 29-32. 
development contribution or an endowment from a developer. ${ }^{51}$ This can be in the form of a development charge, which is the payment of an amount of money or the provision of infrastructure such as the installation of bulk engineering services. The South African National Treasury Department issued a Draft Policy Framework for Municipal Development Charges in $2011^{52}$ and most municipalities have developed similar policies. The payment of development contributions or endowments is an integral part of the process of the subdivision of land. ${ }^{53}$

A condition of approval may be waived or amended or an additional condition may be imposed but only after advertisement, the consideration of objections, and consultation with the owner of the land and the municipality. ${ }^{54}$

These conditions of approval constitute deprivations of property (unless excessive) in terms of section 25(1) of the Constitution of the Republic of South Africa, $1996 . .^{55}$ In the United States of America a similar situation exists, where these conditions are known as "exactions". ${ }^{6}$ An exaction comprises "an assortment of techniques employed by local authorities to compel a developer, either by regulation, negotiation, or simple leverage, to exchange land, money, materials, or services for permission to develop". 57 Typically, exactions require contributions toward public improvements that either fall outside the boundary of subdivisions (such as access roads or off-site drainage easements), or that will serve larger segments of communities in addition to the specified subdivisions (such as new parks). The underlying and common legal issue with respect to exactions is the connection or "essential nexus"58 and "rough

$51 \quad$ Van Wyk Planning Law 369.

52 See City of Cape Town 2013 http://www.capetown.gov.za/en/PublicParticipation/ Documents/HYS_Development_Charges_Policy_Engineering_Serv_Oct_202013.pd f 4.

53 LUPO s 42. Also see KwaZulu-Natal Planning and Development Act 6 of 2008 s 36; Town-planning and Townships Ordinance 15 of 1986 (Transvaal) ss 71(2), 81(2). Also see Herbert Holbrow (Pty) Ltd v Cape Divisional Council 19881 SA 387 (C); South Peninsula Municipality v Malherbe 19992 SA 966 (C) (hereafter Malherbe); Hayes v Minister of Housing, Planning and Administration, Western Cape 19994 SA 1229 (C); Helderberg para 37; Club Mykonos para 36; Shelf-Line. Also see Pienaar 1992 Obiter 1-26.

$54 \quad$ LUPO s 42(3). Also see Shelf-Line paras 29-32.

55 Van der Walt Constitutional Property Law 290; Van Wyk Planning Law 369.

56 Van der Walt Constitutional Property Law 290-291.

57 Schwartz Date Unknown http://www.bc.edu/content/dam/files/schools/law/lawreviews /journals/bcealr/28_4/12_TXT.htm.

$58 \quad$ Nollan v California Coastal Commission 483 US 825 (1987). 
proportionality" 59 between the contribution that is required of the landowner who applies for development or subdivision permission and the expected impact that the proposed development will have on the existing infrastructure. ${ }^{60}$ Without this link, land development regulations may be deemed unconstitutional takings of property without just compensation.

The Sonstraal Heights subdivision process comprised three phases, each of which was approved in turn, and each of which was subject to numerous conditions of approval. A significant condition in the case of Arun was the restriction of vehicular access off the roads in question. This points to the roads being external to the development and not for normal need. What is significant is that although section 42(2) of LUPO permits the imposition of conditions relating to the cession of land without compensation, the approvals did not set a condition that the portions of the planned primary roads that ran over the property had to be ceded to the City at no cost. ${ }^{61}$

The granting of approval of the subdivision that contains the conditions of approval, including development contributions, entails a decision by the municipality. In a constitutional context this is administrative action, which is regulated by the provisions of section 33 of the Constitution and the Promotion of Administrative Justice Act 3 of 2000 (PAJA). A question that can be asked is whether the decisions (approvals) in Arun complied with the requirements for just administrative action. ${ }^{62}$ If the decisions were flawed they could be set aside or partially set aside. In this regard it is important to determine whether the imposition of the conditions of approval as part of the decision in terms of section 42(2) of LUPO is the same as the automatic vesting of roads in terms of section 28 of LUPO.

In my opinion, the imposition of conditions of approval after consideration of an application that includes an agreement arising from the relationship between the municipality and the developer is not the same as the section 28 vesting of roads, which is the automatic legal consequence of the confirmation of a subdivision. ${ }^{63}$ That brings us to section 28 .

\footnotetext{
59 Dolan v City of Tigard 512 US 374 (1994).

60 See Van der Walt Constitutional Property Law 216 fn 73.

61 Arun CC para 10.

62 Originally an alternative claim by Arun was related to the issue that the city had acted ultra vires the provisions of the Ordinance - see Arun CC paras 63-67.

63 Club Mykonos para 37.
} 


\section{Section 28 of LUPO}

\subsection{Public and private roads}

As in the United States and the United Kingdom, a distinction can generally be drawn between private or "unadopted" roads and public or "adopted" roads. ${ }^{64} \mathrm{~A}$ private road typically services a subdivision and is owned and maintained by the community comprising the subdivision. Private roads are usually found in enclosed neighbourhoods or gated communities. When an existing neighbourhood becomes an enclosed neighbourhood, the public roads must be closed. The closure of a public road entails an application and the ownership reverts to the original owner, ${ }^{65}$ who henceforth has a duty to maintain it.

A public road is one that has been established by a municipality or that has been taken over by or vested in the municipality when a new subdivision or township is established, which the public has a right to use. The municipality is responsible for maintaining and upgrading the public road after confirmation of approval. Roads are not registered in the Deeds Office, but they vest ex lege - described as "the passing of ownership to a local authority without the need for formal transfer of ownership". .6

A public road is shown on a general plan or diagram of a township and its width is indicated. There are recognised standards set out in various manuals such as the Blue Book, Red Book and provincial Road Access Policy that set out a road hierarchy and road reserve requirements which can be used to determine normal needs. ${ }^{67}$ Determining normal need is a factual process for which these manuals can be used. Normal need, in the context of the facts of this case, is a road of $16 \mathrm{~m}$ wide. Any land that is vested over and above the $16 \mathrm{~m}$ would be excess land.

\subsection{Interpretation}

All provincial legislation provides that, upon the subdivision of land or the establishment of the township, the ownership of all land taken up by public streets and public places vests in the authority in whose area of

64 eThekwini Municipality v Brooks 2010 ZASCA 74 (27 May 2010). "Adopted" and "unadopted" is UK terminology.

65 See eg SPLUMA Sch 1(g)(vi).

66 Arun 2012 ZAWCHC para 19 referring to Helderberg.

67 Indicated in the statement of Mr GC Underwood, supplied to the author by the developer. The expert evidence of Mr Underwood is referred to in Arun CC paras 51. 52. 
jurisdiction they are situated. ${ }^{68}$ While provincial legislation generally provides for the vesting of streets in a municipality on approval of a subdivision or township, both the Cape and Northern Cape legislation contain a unique provision that refers to the vesting of roads without compensation if the provision of the streets is based on the normal need arising from the subdivision. To obtain a proper understanding of the context it is important to quote the whole of section 28 of LUPO:

\section{Ownership, on subdivision, of public streets and public places}

The ownership of all public streets and public places over or on land indicated as such at the granting of an application for subdivision under section 25 shall, after the confirmation of such subdivision or part thereof, vest in the local authority in whose area of jurisdiction that land is situated, without compensation by the local authority concerned if the provision of the said public streets and public places is based on the normal need therefor arising from the said subdivision or is in accordance with a policy determined by the Administrator from time to time, regard being had to such need. ${ }^{69}$

Section 28 must be read in conjunction with LUPO Regulations 37 and 38 of 1988. Regulation 37 provides that where land in a subdivision is required by a local authority in connection with the supply of services directly related to the needs arising from the subdivision, such land must be surrendered free of charge. Regulation 38 provides that where land is required for a purpose other than that referred to in Regulation 37, it must be purchased at the market value applicable to the total land unit. ${ }^{70}$

In essence section 28 comprises two parts:

The one part vests "ownership of all public streets and public places over or on land indicated as such at the granting" of a subdivision application by a local authority. The other part, which is separated from the first by a comma, provides that the ownership of land vests without compensation if it is based "on the normal need therefor arising from said subdivision", or is in accordance with a normal need policy. ${ }^{71}$

It is important to look at the syntax of the proviso: "if the provision of the said public streets and public places is based on the normal need therefor

68 Northern Cape Planning and Development Act 7 of 1998 s 52; KwaZulu-Natal Planning and Development Act 6 of 2008 s 36; Town-planning and Townships Ordinance 15 of 1986 (Transvaal) s 91; LUPO s 28.

69 See further Malherbe 981G-982G; Helderberg para 34; Club Mykonos para 33.

70 PN 1047 in PG 4563 of 5 December 1988 (Cape) (LUPO Regulations). Also see Underwood Statement para 6.

71 Arun CC para 32. 
arising from the said subdivision". To permit the acquisition of land by the local authority beyond normal needs without compensation is to ignore the syntax of the proviso. Moreover, there must be support for the minority view of Heher $\mathrm{J}$, in Helderberg, that the "correlative of the negative postulation" is that an owner is entitled to compensation for overgenerously provided streets and public places which vest in the local authority. ${ }^{72}$

In addressing the question as to why the ownership of public roads vests in the municipality upon approval of the subdivision it is important to note that land use and development in a municipality must be planned, orderly and public-oriented. A township development envisages new homes, new communities and their general welfare. ${ }^{73}$ The public streets and places properly vest in the public authority without compensation because they are integral to the development. ${ }^{74}$ They are the developer's "give" for the additional value a subdivision approval brings. ${ }^{75}$ After the approval it is the local authority that controls and manages such public places and streets.

The vesting of roads in the municipality applies to all land indicated on the subdivision application as public streets, whether they are based on the normal need or in excess of it. ${ }^{76}$ As a result all public roads vest, even those that are not an integral part of the development - in other words, those that exceed the normal need therefor arising from the subdivision. If only that part of the road that relates to the normal need vested, this would result in a number of inconsistencies. One would have to determine which part of the road vested, the plans of the subdivision would have to indicate this, and the developer would be left with the excess, with which it could do nothing. This could amount to a constructive expropriation (of a part of a road) ${ }_{, 7}^{77}$ the recognition of which is seen as being unsuitable in South Africa. ${ }^{78}$

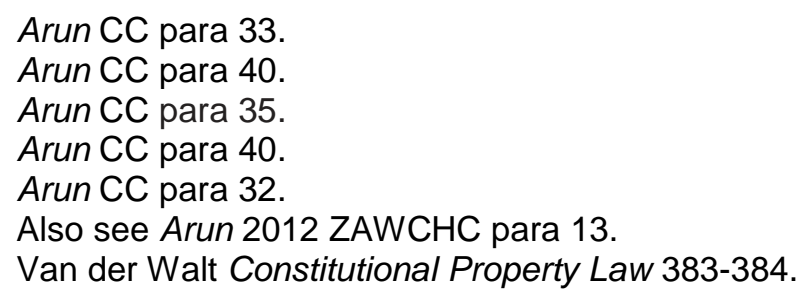




\subsection{Is the vesting of the ownership of roads an expropriation for which compensation is payable?}

The Constitutional Court held that "section 28 is an ex lege transfer of ownership that has the same effect as an expropriation". ${ }^{79}$ This is also clear from the statement by Moseneke DCJ that "I would rather save the provision by giving it a meaning that is at peace with section 25(2) of the Constitution". 80

In the minority judgment in Helderberg, ${ }^{81}$ which found support in the Constitutional Court, ${ }^{82}$ Heher JA had stated that:

In theory the automatic vesting of land occurs in terms of $s 28$ at the voluntary instance of the landowner who elects to rezone his land, provides for roads and public places in his application for subdivision and causes the subdivision to be confirmed. But that is to ignore the substance. It is not the owner's choice whether or not to give such land to the local authority but the unavoidable result of a statutory provision which applies to all cases.... Thus, the provisions of $\mathrm{s}$ 28 , although primarily concerned with the vesting of land, are founded in a compulsory taking ...

None of these statements unequivocally answers the question whether the vesting of the ownership of roads in a municipality amounts to an expropriation. Ownership is transferred from the developer to the municipality by operation of law. What is the legal nature of this "transaction"? Is it merely another form of "transfer" of ownership in specific circumstances, namely where land is subdivided or a township established? Since ownership of the roads is not transferred by means of registration in the Deeds Office, a constitutive element for the transfer of immovable property is not present. Consequently, ownership could pass in terms of a form of original acquisition. ${ }^{83}$

On the other hand, one could ask whether section 28 amounts to an expropriation provision without employing the term "expropriation" and without reference to an expropriating authority. Section 25(2) of the Constitution provides that property may be expropriated for a public purpose or in the public interest and subject to compensation. Section 25 (3) deals with the payment of compensation and the circumstances or factors that must be taken into account, one of which could be the purpose

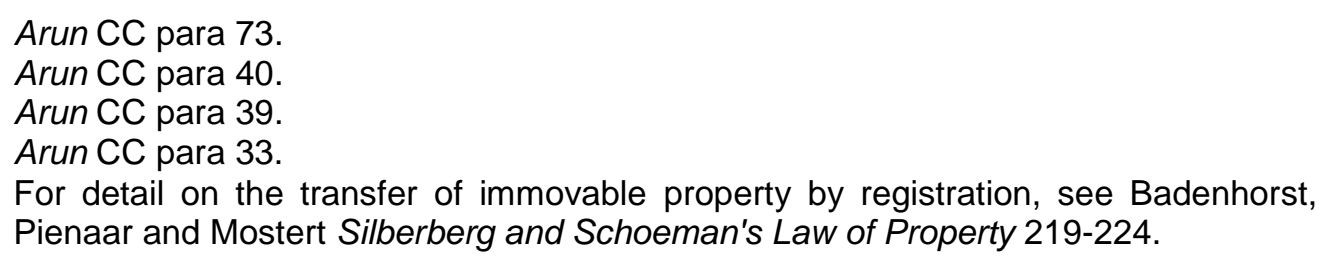


of the expropriation. Van der Walt states ${ }^{84}$ that it is possible, in terms of section 25(3), that in suitable cases, expropriation could be just and equitable without any compensation. If one were to examine the factors that play a role in determining the amount of compensation payable, an argument could be made out to support the idea that, in terms of section 28, land for a road must be expropriated without compensation because it is an integral part of the subdivision - in other words where the purpose of the expropriation is to provide for roads. In addition, section 36 of the Constitution, where factors such as the importance of the purpose of the limitation and the nature and extent of the limitation $^{85}$ are listed, the possibility of awarding no compensation could be real. If one looks at the purpose of section 28, it could be argued that in cases of the vesting of land in a municipality during the process of the subdivision of land, no compensation is required.

Consequently, land that is required for a public road that is within the normal need arising from the subdivision could amount to an expropriation without compensation. What must be stressed is that this would apply to that part of the internal road that is required for normal need only. Any land that vests over and above normal need would require compensation. The judgment of the Constitutional Court must be quoted here:

\footnotetext{
Where the extent of the roads provided for in the plan is beyond the normal need, the local authority must compensate the developer for the excess that vests in it. This excess is not related to, and the need for it precedes and is not created by, the subdivision. ${ }^{86}$
}

The principle is adhered to that expropriation attracts compensation. The Cape High Court indicates that

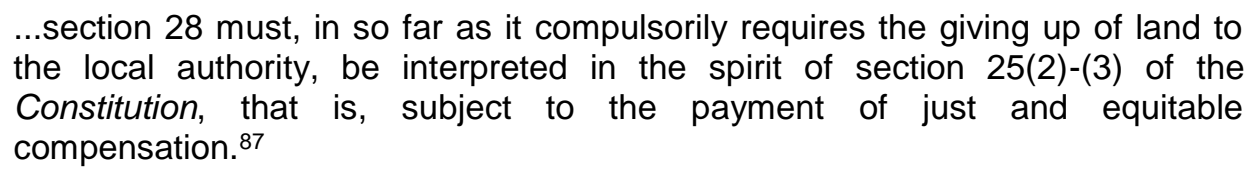
the local authority, be interpreted in the spirit of section 25(2)-(3) of the Constitution, that is, subject to the payment of just and equitable compensation. ${ }^{87}$

However, there are exceptions, and the vesting of roads for a subdivision or township could be one of them.

The vesting of the ownership of a public road in a municipality upon subdivision or township establishment cannot amount to an expropriation. This is borne out by a number of factors. First, while I view section 42(2)

\footnotetext{
84 Van der Walt Constitutional Property Law 506.

85 Constitution s 36(1)(b)-(c).

86 Arun CC para 35.

87 Arun 2012 ZAWCHC para 41.
} 
development contributions as being different from section 28 vesting, their effect and constitutional property context is the same. As a result both of them amount to section 25(1) deprivations. Secondly, in conveyancing practice a distinction is made between vesting transfers, private sales and expropriation transfers. ${ }^{88}$ In Groenewald $v$ Pieters ${ }^{89}$ Makgoba J dealt with the applicability of section 118(1) of the Local Government: Municipal Systems Act 32 of 2000 (MSA) on the transfers of properties of which SANRAL had become the owner through vesting ${ }^{90}$ and of which it had become owner through expropriation. ${ }^{91} \mathrm{He}$ stated that it could never have been the intention of the legislature that the provisions of section 118(1) of the MSA should be applicable to vesting transfers, and accepted the argument that:

.... vesting transfer stands in contradistinction to a private sale. With vesting ... ownership passes immediately on incorporation of the applicant and the registration of transfer serves only one purpose namely to confirm a historical fact, that is the transfer of ownership which has already occurred. With a private sale the purchaser has acquired no proprietary rights in the property which forms the subject thereof before registration of transfer of ownership of that property. It presupposes the transfer of ownership from one person to another by a deed of transfer. ${ }^{92}$

Moreover, section 26(3) of the Expropriation Act 63 of 1975 provides that:

In the case of land which is in terms of an ordinance declared to be a road or acquired for a road without such land being expropriated, the following provisions shall apply, namely -

(a) notwithstanding anything to the contrary contained in any such ordinance -

(i) the compensation to which the owner is entitled, shall be calculated, determined and paid in accordance with section 12, as if the land to which the declaration or acquisition relates had been expropriated in terms of the provisions of this Act;

When an authority requires land for a road, it has different options. It can purchase the land in a private sale and transfer the land by registration, it can expropriate the land, or the land can vest in certain circumstances,

88 See further Anon 2015 http://www.ghostdigest.co.za/articles/vesting-transfers-andexpropriations $/ 54264$.

89 Groenewald v Pieters 2009 ZAGPPHC 60 (15 May 2009) para 15. Also see South African National Roads Agency Ltd v Chief Registrar of Deeds 2009 ZAGPPHC 160 (31 March 2009) para 15 (identical wording).

90 In terms of s 7(2) of the South African National Road Agency and National Roads Act 7 of 1998.

91 In terms of $\mathrm{s} 41$ of the South African National Road Agency and National Roads Act 7 of 1998 read with ss 7-24 of the Expropriation Act 63 of 1975.

92 Groenewald v Pieters 2009 ZAGPPHC 60 (15 May 2009) para 15. 
such as where it is required for public roads that are required for the subdivision.

\section{Implications of Arun on new spatial planning legislation}

The wording of section 28 of LUPO contains the phrase "normal need therefor arising from the subdivision". This limits or restricts the amount of land that can be taken up by a public road that can vest in the municipality. The use of this land is restricted so that the developer can subdivide the land. As has been mentioned, only LUPO and the Northern Cape legislation contain this phrase. While other provincial planning legislation also provides for the vesting of public roads in the municipality, the language differs and it may well be possible that a municipality could insist on taking too much land from a developer. Are there then safeguards for a developer? An answer to this question necessitates a look at the planning legislative framework in South Africa.

The legislative situation in respect of planning in South Africa is complex. LUPO and all other old-order planning legislation has, since 1 July 2015, effectively been superseded by a new framework national SPLUMA. While SPLUMA did not repeal LUPO and all the other provincial planning legislation $^{93}$ it has in essence nullified them because it prohibits an alternative or parallel mechanism, measure, institution or system on spatial planning, land use, land use management and land development in a manner inconsistent with its provisions. ${ }^{94}$ SPLUMA envisages a situation where provincial planning legislation can be enacted but the main thrust of SPLUMA is to create a system whereby municipalities enact municipal planning by-laws. The Western Cape is the only province that has to date enacted new provincial planning legislation by means of its LUPA. ${ }^{95}$

SPLUMA itself contains no direct provision to regulate the vesting of roads in a municipality on the establishment of a township. A "township" is defined as "an area of land divided into erven, and may include public

93 Townships Ordinance 9 of 1969 (Orange Free State); LUPO; Town-planning and Townships Ordinance 15 of 1986 (Transvaal); Northern Cape Planning and Development Act 7 of 1998 and the KwaZulu-Natal Planning and Development Act 6 of 2008; Proc R293 GG 373 of 16 November 1962 (Regulations for the Administration and Control of Townships in Black Areas); GN R1897 in GG 10431 of 12 September 1986 (Regulations for the Administration and Control of Townships in Black Townships); GN R1886 in GG 12688 of 3 August 1990 (Township Development Regulations for Towns). See further Van Wyk Planning Law 43-49.

94 SPLUMA S 2(2).

95 It came into operation on 1 July 2015 in the City of Cape Town. 
places and roads indicated as such on a general plan". Only "public place" is defined, as follows:

\begin{abstract}
...any open or enclosed place, park, street, road or thoroughfare or other similar area of land shown on a general plan or diagram that is for use by the general public and is owned by, or vests in the ownership of, a municipality, and includes a public open space and a servitude for any similar purpose in favour of the general public;
\end{abstract}

Neither SPLUMA nor the SPLUMA Regulations ${ }^{96}$ contain any further reference to the vesting of roads on the establishment of a township.

It is therefore left to provincial legislation and municipal by-laws to amplify the obligations of developers to provide for roads. The only province to have enacted such provincial legislation is the Western Cape. There, LUPA's long title indicates that its aim is to regulate, support and monitor the municipal planning and regulation of public places and municipal roads arising from subdivisions. LUPA provides that in the process of the subdivision of land, a municipality must make provision for the vesting of the ownership or the registration of public places as well as when such vesting occurs or when registration is effected. ${ }^{97}$ In a definition identical to that in SPLUMA, roads are included in the definition of "public place". However, LUPA contains a provision similar to section 28 of LUPO, namely:

\begin{abstract}
A municipality is not liable for compensation for the land (earmarked for a public place) if the provision of the public place is based on the normal need therefor arising from the subdivision. ${ }^{98}$
\end{abstract}

Since LUPO informed the content of the Northern Cape Planning and Development Act, the latter also contains a provision similar to those in both $\angle U P O$ and $L U P A .^{99}$

No other provincial legislation has been promulgated yet, but since SPLUMA is drafted in such a way as to enable municipalities to draft their own municipal by-laws, a number of municipalities are in the process of doing just that. Unfortunately few are publicly available and those that are

96 GN R239 in GG 38594 of 23 March 2015 (Spatial Planning and Land Use Management Act Regulations).

$97 \quad$ LUPA s 36(4)(a). See also s 37(1).

98 LUPA s 37(2).

99 The Northern Cape Planning and Development Act s 52(1) provides that: "The ownership of all land taken up by public streets and public places ... shall, after the confirmation of the subdivision..., vest in the authority, and that authority shall not pay compensation for it if the provision of the public streets or public places is based on the normal need for them arising from the subdivision...". 
vary considerably in content. Moreover, few have clear provisions regarding the vesting of the ownership of public places or public roads in the municipality without compensation if the provision is based on normal needs. Municipalities in the Western and Northern Cape are guided by provincial legislation. As a result the by-laws of the municipalities in these provinces should reflect the content of the provincial legislation, which contains the "normal needs" provision. A by-law that does contain such a provision is the City of Cape Town's Draft Municipal Planning By-law, $2014,{ }^{100}$ providing that the ownership of all land designated as a public place on an approved plan of subdivision vests in the City upon confirmation of the subdivision without compensation, if the City considers the provision of the public place to be a normal need arising from the subdivision.

Interestingly, the Draft By-law on Municipal Land Use Planning ${ }^{101}$ proposed by Stellenbosch provides only that when the municipality approves a development application which provides for the use of land for residential purposes, the applicant may be required to provide land for parks or public open space. ${ }^{102}$

Outside of these two provinces and the municipalities specified the picture is less clear. One province, KwaZulu-Natal, is in the process of drafting a generic provincial by-law to be known as the Generic Municipal Spatial Planning and Land Use Management By-law. ${ }^{103}$ Of the municipalities that have adopted the generic by-law, both the Umlazi Local Municipality and the Umgungundlovu District Municipality's by-laws provide that where land is required for a public road, it must be transferred to the municipality at the cost of the developer and the ownership vests in the municipality. ${ }^{104}$

100 City of Cape Town 2014 https://www.capetown.gov.za/en/Planningportal/Documents/HYS_Municipal_planning_bylaw_draft_complete.pdf. The relevant parts of $s$ 55 are: "(1) The ownership of all land designated as a public place on an approved plan of subdivision, vests in the City upon confirmation of the subdivision or a phased part thereof. (5) The City is not liable for compensation for the land referred to in subss (1) or (2) if the City considers the provision of the public place to be a normal need arising from the subdivision".

101 Stellenbosch 2014 http://www.stellenbosch.gov.za/af/documents/by-laws/1515-draftby-law-on-municipal-land-use-planning-june-2014/file.

102 Stellenbosch 2014 http://www.stellenbosch.gov.za/af/documents/by-laws/1515-draftby-law-on-municipal-land-use-planning-june-2014/file s 81(1).

103 While the KwaZulu-Natal Generic Municipal Spatial Planning and Land Use Management By-laws 2015 are not publicly available, some municipalities such as Umlazi and Umgungundlovu refer, in their by-laws, to the generic by-laws.

104 Umlazi Local Municipality 2015 (Spatial Planning and Land Use Management Bylaw) http://www.umlalazi.org.za/media/52138/draft_spluma_kzn_model.pdf s 61; Umgungundlovu District Municipality 2015 (Model Spatial Planning and Land Use 
With regard to individual municipalities that have drafted by-laws, the City of Tshwane Draft Land Use Management By-law indicates that public places vest in the municipality and the township developer shall not be entitled to compensation. ${ }^{105}$ The Mbombela Spatial Planning and Land Use Management By-law ${ }^{106}$ states that the ownership of land that is earmarked for a public place as shown on an approved subdivision plan vests in the municipality upon confirmation of the subdivision. ${ }^{107}$ In Limpopo the Thulamela Local Municipality's Spatial Planning and Land Use Management By-laws ${ }^{108}$ provide for the imposition of "reasonable conditions" of approval that must arise from the approval of the proposed utilisation of land. These include:

...the endorsement in terms of section 31 of the Deeds Registries Act in respect of public places where the ownership thereof vests in the municipality or the registration of public places in the name of the municipality... ${ }^{109}$

What is clear from the variety of provisions is that the situation with regard to the vesting of the ownership of land without compensation on approval of a subdivision is established. However, what are less clear are the parameters within which this must take place. Section 28 of LUPO, its successors LUPA and the Northern Cape Planning and Development Act, and the interpretation in Arun, safeguard a developer against the vesting of excess land in a municipality because of the normal needs proviso. In the absence of proper guidance from SPLUMA, other provinces and municipalities have drafted legislation that contains different and widelyphrased provisions regarding the vesting of the ownership of land for public roads on township establishment. There is no proviso similar to that

Management By-laws) http://www.mkhambathini.gov.za/corporate/bylaws/2015/ umdm-by-laws.pdf s 62 .

105 City of Tshwane 2015 http://www.tshwane.gov.za/sites/Departments/City-Planningand-Development/Draft\%20Land\%20Use\%20Management\%20ByLaw\%202015/ Draft\%20Tshwane\%20Land\%20Use\%20Management\%20By-Law\%202015.pdf. S 20(16) provides that: "After notice have been given in terms of the provisions of this By-law public places shall vest in the Municipality and an applicant shall not be entitled to compensation therefor read with section 63 of the Local Government Ordinance, 1939 (Ord. 17 of 1939)". S 63 provides that: "The council shall have control and management of all roads, streets.... Which have been or shall at any time set apart and appropriated by proper authority for the use and benefit of the public, or to which the inhabitants of the municipality shall at any time have acquire a common right".

106 LAN 79 in PG 2503 of 10 July 2015 (Mpumalanga) (Mbombela Local Municipality By-law on Spatial Planning and Land Use Management).

107 LAN 79 in PG 2503 of 10 July 2015 (Mpumalanga) s 67(1).

108 LAN 57 in PG 2517 of 8 June 2015 (Limpopo) (Thulamela Local Municipality Spatial Planning and Land Use Management By-laws).

109 LAN 57 in PG 2517 of 8 June 2015 (Limpopo) s 52(1)(m). 
in section 28 of LUPO. This is a concern, and developers would do well to draft their agreements with municipalities with care.

\section{Conclusions}

In the specific context of the subdivision of land or township establishment, where the internal roads are an integral part of a subdivision, are to be used by the public and maintained by the relevant municipality, the ownership of the land vests in the municipality without compensation. Land that has vested that is beyond the normal need - excess land requires compensation. Despite the fact that excess land vests in the municipality and attracts compensation, this is not an expropriation.

However, looking ahead, and particularly in the context of the wide vesting provisions in recent planning legislation, the decision in Arun underscores that a narrow legal road must be followed. Should municipalities exact too much land for public roads, severe constitutional property implications could result.

\section{Bibliography}

\section{Literature}

Badenhorst, Pienaar and Mostert Silberberg and Schoeman's Law of Property

Badenhorst PJ, Pienaar JM and Mostert H Silberberg and Schoeman's The Law of Property $5^{\text {th }}$ ed (Durban LexisNexis Butterworths 2006)

Pienaar 1992 Obiter

Pienaar JM "Die Regsaard van Dorpstigtingsvoorwaardes" 1992 Obiter 126

Pienaar Land Reform

Pienaar JM Land Reform (Juta Cape Town 2015)

Underwood Statement

Underwood GC Statement by GC Underwood, Registered Professional Planner in Connection with Arun Property Developments (Pty) Ltd (supplied to the author)

Van der Walt Constitutional Property Law

Van der Walt AJ Constitutional Property Law $3^{\text {rd }}$ ed (Juta Cape Town 2011 
Van Wyk Planning Law

Van Wyk J Planning Law $2^{\text {nd }}$ ed (Juta Cape Town 2012)

Case law

\section{South Africa}

Arun Property Development (Edms) Bpk v Stad Kaapstad 2005 ZAWCHC 86 (15 November 2005)

Arun Property Development (Pty) Ltd $v$ City of Cape Town 2012 ZAWCHC 399 (31 October 2012)

Arun Property Development (Pty) Ltd v City of Cape Town 20152 SA 584 (CC)

City of Cape Town v Arun Property Developments (Pty) Ltd 2014 ZASCA 56 (16 April 2014)

City of Cape Town v Helderberg Park Development (Pty) Ltd 20086 SA 12 (SCA)

Club Mykonos Langebaan Ltd v Langebaan Country Estate Joint Venture 20093 SA 546 (C)

Ehlers v MEC: Dept of Environmental Affairs and Development Planning 20081 All SA 576 (C)

Esterhuyse $v$ Jan Jooste Family Trust 19984 SA 241 (C)

eThekwini Municipality v Brooks 2010 ZASCA 74 (27 May 2010)

Groenewald v Pieters 2009 ZAGPPHC 60 (15 May 2009)

Hayes $v$ Minister of Finance and Development Planning, Western Cape 20034 SA 598 (C)

Hayes $v$ Minister of Housing, Planning and Administration, Western Cape 19994 SA

1229 (C)

Herbert Holbrow (Pty) Ltd v Cape Divisional Council 19881 SA 387 (C)

Huisman $v$ Minister of Local Government, Housing and Works (House of Assembly) 19961 SA 836 (A)

Lagoon Bay Lifestyle Estate (Pty) Ltd v The Minister of Local Government, Environmental Affairs and Development Planning of the Western Cape 20114 All SA 270 (WCC) 
Municipality of Stellenbosch v Shelf-Line 104 (Pty) Ltd 20121 SA 599 (SCA)

Reflect-All 1025 CC v MEC for Public Transport, Roads and Works, Gauteng Provincial Government 20096 SA 391 (CC)

South African National Roads Agency Ltd v Chief Registrar of Deeds 2009 ZAGPPHC 160 (31 March 2009)

South Peninsula Municipality v Malherbe 19992 SA 966 (C)

Waenhuiskrans Arniston Ratepayers Association $v$ Verreweide Eiendomsontwikkelings (Edms) Bpk 20113 SA 434 (WCC)

\section{United States of America}

Dolan v City of Tigard 512 US 374 (1994)

Nollan v California Coastal Commission 483 US 825 (1987)

\section{Legislation}

Constitution of the Republic of South Africa, 1996

Expropriation Act 63 of 1975

KwaZulu-Natal Planning and Development Act 6 of 2008

Land Use Planning Ordinance 15 of 1985 (Cape)

Local Government: Municipal Systems Act 32 of 2000

Northern Cape Planning and Development Act 7 of 1998

Promotion of Administrative Justice Act 3 of 2000

South African National Road Agency and National Roads Act 7 of 1998

Spatial Planning and Land Use Management Act 16 of 2013

Town-planning and Townships Ordinance 15 of 1986 (Transvaal)

Townships Ordinance 9 of 1969 (Orange Free State)

Western Cape Land Use Planning Act 3 of 2014

\section{Government publications}

GN R239 in GG 38594 of 23 March 2015 (Spatial Planning and Land Use Management Act Regulations)

GN R1886 in GG 12688 of 3 August 1990 (Township Development Regulations for Towns) 
GN R1897 in GG 10431 of 12 September 1986 (Regulations for the Administration and Control of Townships in Black Townships)

LAN 57 in PG 2517 of 8 June 2015 (Limpopo) (Thulamela Local Municipality Spatial Planning and Land Use Management By-laws)

LAN 79 in PG 2503 of 10 July 2015 (Mpumalanga) (Mbombela Local Municipality By-law on Spatial Planning and Land Use Management)

PN 1047 in PG 4563 of 5 December 1988 (Cape) (LUPO Regulations)

Proc R293 of 1962 in GG 373 of 16 November 1962 (Regulations Relating to Township Establishment and Land Use)

\section{Internet sources}

Anon 2015 http://www.ghostdigest.co.za/articles/vesting-transfers-andexpropriations $/ 54264$

Anon 2015 Vesting Transfers and Expropriations http://www.ghost digest.co.za/articles/vesting-transfers-and-expropriations/54264 accessed 25 August 2015

City of Cape Town 2013 http://www.capetown.gov.za/en/Public Participation/Documents/HYS_Development_Charges_Policy_Engineerin g_Serv_Oct_202013.pdf

City of Cape Town 2013 Development Charges Policy for Engineering Services for the City of Cape Town http://www.capetown.gov.za/en/Public Participation/Documents/HYS_Development_Charges_Policy_Engineerin g_Serv_Oct_202013.pdf accessed 5 September 2015

City of Cape Town 2014 https://www.capetown.gov.za/en/Planningportal/ Documents/HYS_Municipal_planning_bylaw_draft_complete.pdf

City of Cape Town 2014 Draft Municipal Planning By-law https://www.capetown.gov.za/en/Planningportal/Documents/HYS_Municip al_planning_bylaw_draft_complete.pdf accessed 25 August 2015

City of Tshwane Metropolitan Municipality http://www.tshwane.gov.za/sites/Departments/City-Planning-and Develop ment/Draft\%20Land\%20Use\%20Management\%20ByLaw\%202015/Draft \%20Tshwane\%20Land\%20Use\%20Management\%20By-Law\%202015. pdf

City of Tshwane Metropolitan Municipality 2015 Draft Land Use Management By-law http://www.tshwane.gov.za/sites/Departments/CityPlanning-and-Development/Draft\%20Land\%20Use\%20Manage 
ment\%20ByLaw\%202015/Draft\%20Tshwane\%20Land\%20Use\%20Manag ement\%20By-Law\%202015.pdf accessed 26 August 2015

Schwartz Date Unknown http://www.bc.edu/content/dam/files/ schools/law/lawreviews/journals/bcealr/28_4/12_TXT.htm

Schwartz BK Date Unknown Development Agreements http://www.bc.edu/content/dam/files/schools/law/lawreviews/journals/bcea Ir/28_4/12_TXT.htm accessed 25 August 2015

Stellenbosch 2014 http://www.stellenbosch.gov.za/af/documents/bylaws/1515-draft-by-law-on-municipal-land-use-planning-june-2014/file Stellenbosch 2014 Draft By-law on Municipal Land Use Planning http://www.stellenbosch.gov.za/af/documents/by-laws/1515-draft-by-lawon-municipal-land-use-planning-june-2014/file accessed 20 August 2015

Umlazi Local Municipality 2015 http://www.umlalazi.org.za/ media/52138/draftspluma_kzn_model.pdf;

Umlazi Local Municipality 2015 Spatial Planning and Land Use Management By-law http://www.umlalazi.org.za/media/52138/ draft_spluma_kzn_model.pdf accessed 13 March 2016

Umgungundlovu District Municipality 2015http://www.mkhambathini.gov. za/corporate/bylaws/2015/umdm-by-laws.pdf.

Umgungundlovu District Model Spatial Planning and Land Use Management By-laws http://www.mkhambathini.gov.za/corporate/

bylaws/2015/umdm-by-laws.pdf accessed 13 March 2016

\section{List of Abbreviations}

LUPA

LUPO

$M S A$

PAJA

SANRAL

SPLUMA
Land Use Planning Act 3 of 2014 (Western Cape)

Land Use Planning Ordinance 15 of 1985 (Cape)

Local Government: Municipal Systems Act 32 of 2000

Promotion of Administrative Justice Act 3 of 2000

South African National Road Agency Limited

Spatial Planning and Land Use Management Act 16 of 2013 